\title{
SOCIAL THEORY AND PEASANT REVOLUTION IN VIETNAM AND GUATEMALA
}

JEFFERY M. PAIGE

When the first American marines arrived in Vietnam March 1965 they were, according to Philip Caputo, who was one of them, guided to the beaches of Danang (Tourane in Colonial Vietnam) by maps drawn by French cartographers. Similarly, American policy makers would have found, had they chosen to look, their best guide to the sociology of the quagmire in the works of such French scholars as Yves Henry and Pierre Gourou. Gourou's classic The Peasants of the Tonkin Delta remains the starting point for all later writing about peasant revolution in Vietnam, but the long American involvement produced what James Scott has called a "boomlet" in the study of peasant revolution in Vietnam and elsewhere.' As the United States increases its military involvement in Central America it seems appropriate to inquire whether any of the scholarly theories developed in the earlier experience in Vietnam might generalize to fit still another peasant revolution half a world away. Neither sound foreign policy nor good social theory can be based on "explanations" which in fact apply only to one time and place. Consideration of the Central American revolution and the case of Guatemala in particular should provide information about both. The goal of this article, however, is principally theoretical; to test theories developed to explain one case, Vietnam, in a second and largely independent case, Guatemala.

Scholarly analysis of the problem of peasant revolution in Vietnam has led to three different sets of theories, all of which make somewhat different predictions about the causes of peasant revolution in Vietnam and elsewhere and are, furthermore, at least in large part, mutually exclusive. The three theoretical perspectives might be called moral economy, political economy, and class conflict. The first two terms were used by Samuel Popkin in his book The Rational Peasant to distinguish his own perspective on Vietnam, which he calls "political economy," from the perspective he calls "moral economy,"

Center for Research on Social Organization, University of Michigan.

Copyright $\odot 1983$ by Jeffery M. Paige 
after the title of James Scott's study of depression-era rebellions in Burma and Vietnam, The Moral Economy of the Peasant. "Moral economists" include not only Scott but also Eric Wolf, Joel Migdal and, to a lesser extent, Paul Mus and his students John McAlister and Frances Fitzgerald. ${ }^{2}$ Since political economy sometimes implies the Marxist variety associated, for example, with the Union of Radical Political Economists, it is important to note that Popkin's political economy has a distinctly conservative cast and draws not on Marx but on the work of such American political theorists as Frohlich, Oppenheimer and Young, Mancur Olson, Brian Barry, and even Edward Banfield. ${ }^{3}$ This leaves, obviously, a third interpretation which, to distinguish it from conservative political economy and avoid interminable debate over what is and is not Marxist, might be called "class conflict." This position in the interpretation of the Vietnamese revolution I claim for myself although it is very likely that of the revolutionaries themselves. ${ }^{4}$

The three perspectives - moral economy, political economy, and class conflict - are not products of idiosyncracies of the Vietnamese case but rather of regularities in the structure of social movement theory. They are in fact representative of three general traditions in the study of social movements which Charles Tilly has called, respectively, Durkheimian, Millian and, with more courage than I can muster here, Marxist. Popkin and his fellow "political economists" can be unequivocally assigned to Tilly's Millian category by direct attribution. Millians, whom Tilly traces to the Utilitarian tradition of John Stuart Mill, can be identified by their affection for rational individuals guided by explicit decision rules and by their corresponding lack of interest in or, as Tilly would have it, fear of, class based political action. 5 Popkin and associates are Millians not only because the subject of his book is "rational" peasants but also because he explicitly acknowledges his intellectual debt to theorists such as Mancur Olson and Frohlich, Oppenheimer and Young who are named by Tilly as part of the Millian school. ${ }^{6}$ Characteristically, Popkin begins his book by evoking an image of Millian calculation in this quotation from Pierre Gourou:

\footnotetext{
We cannot help being astonished by the subtlety, the intrigue, of which a simple peasant is capable, when his wretched appearance might make one believe that he doesn't see beyond the muzzle of his buffalo.?
}

The rational peasant, as described by Popkin or by Gourou as well, is constantly plotting his individual advancement; and usually, although not invariably, at the expense of other less fortunate members of the peasant class. Social solidarity insofar as it exists at all in peasant society depends on political stalemate or stable dominant coalitions, not on any particular 
attachment, either social or emotional, to "folk society" or the "little tradition" or the "closed corporate village."

James Scott, Popkin's exemplary moral economist, begins his book on depression-era rebellions with a quote from Tawney about the position of the rural Chinese population being like ". . that of a man standing permanently up to his neck in water, so that even a ripple might drown him." The imagery of isolated individuals clinging to precarious subsistence in the face of social and economic forces which threaten inundation is a central theme in Scott's book, although the problem is not so much that drowning is inconvenient but rather that it is immoral. Such concerns are characteristic of theorists whom Tilly terms "Durkheimian." They share a common fear of the disruptive effects of industrialism and capitalism and view social movements as responses to the breakdown of social solidarity during rapid change. It would simplify matters considerably if Tilly classified Scott's intellectual associates as Durkheimian just as he classified Popkin's as Millian. Unfortunately, Eric Wolf, whose Peasant Wars of the Twentieth Century, like Popkin's and Scott's books, was written because of and about Vietnam, is directly mentioned by Tilly as an example not of a Durkheimian but, of all things, a Marxist. It is true that Wolf shows a critical concern for the ravages of what he calls "North Atlantic Capitalism," but then Durkheim was equally concerned with the disruptive effects of capitalism on the French side of the North Atlantic and Wolf's comments on the consequences of capitalist expansion have a decidedly Durkheimian ring. Capitalist markets have "... torn men up by their roots and shaken them loose from their social relationships," and for Wolf the "tactically mobile middle peasantry" is the main carrier of revolution because it is both most vulnerable to the changes wrought by capitalism and most dependent on the solidarity of kin and village which these changes disrupt. It is of course difficult to accept the taxonomy while rejecting the taxonomist's judgments, but Wolf's role in theorizing about Vietnam is too important to be ignored, Tilly's taxonomy, too useful to be dropped, and Wolf, too clearly part of the Durkheimian tradition to be reclassified.

The third classification is the least problematic since Tilly kindly uses Agrarian Revolution as an illustration and correctly emphasizes that the work is concerned with the relationship between interest and action, which is the hallmark of his Marxist theoretical type. ${ }^{10}$ Taxonomy is of course a prerequisite, not a substitute, for theory, but the neat parallelism between the directions of explanation of Vietnam and the three traditions in social movement theory indicates that the problems raised by the Vietnamese case are general ones. Their extension to a second case, Guatemala, will answer 
theoretical as well as substantive questions. To do so requires first that the principal propositions from each theory be extracted from a reexamination of the Vietnamese case.

\section{Durkheim, Mill, and Marx in Vietnam}

\section{Durkheim: Moral Economy}

Traditional Vietnamese society was, according to the Durkheimian moral economists, held together by three elements, which Popkin calls "safety first," the village and patron client bonds. " Safety first, or the subsistence ethic, is a moral principle which reflects a widely shared view that a peasant deserves just recompense for his labors in the form of a guaranteed if meager subsistence and that it is the responsibility of his superiors to see that their customary rapacity does not extend to the peasant's mite. The peasant may provide, as Eric Wolf notes, "three bags full - one for my master, one for my dame and one for the little boy who lives down the lane," but he must also provide for himself. ${ }^{12}$ It is immoral for the master to steal not the first three bags but only the last, the one that the peasant needs to live. To do so risks not only deprivation but a violation of the implicit social contract and revolt. But such an implicit contract can be and is violated in peasant society by natural disaster or famine beyond even the landlord's control, and, more directly, by the extractions of a strong state or by the inequities of a commercial market in crops or land. The peasant can be drowned by a natural disaster including, literally, a flood, or be submerged by the combined demands of landlords, the market, and the state.

The village, according to Popkin's description of moral economy, functions to ease the subsistence crisis by providing communal resources such as community land, reciprocal labor exchange, ceremonial funds, communal granaries, mutual aid based on kinship or vicinage, or institutionalized social pressures to redistribute wealth to gain status in the village civil-religious hierarchy. Village social structure, then, functions as a form of social insurance to protect peasants from violation of the subsistence minimum.

If village social insurance fails and the subsistence minimum is endangered, the lord may still extend a helping hand in the form of patron-client ties which, whatever their overtones of paternalism and subordination, allow the peasant one more source of money, political influence, and social prestige when he needs them most. Rents may be forgiven, loans reduced or interest not collected, medical expense paid, burial plots donated, tax collectors suborned, and the sherrif dissuaded by a landlord who values social prestige and political support more than money. 
It is, however, at just those times when the subsistence minimum is most endangered that the village's insurance system and the patron's generosity are likely to vanish. Natural disasters impoverish villages and landlords as well as peasants, the market replaces communal ties with calculation and turns patrons into rent collectors, and the state, if strong enough, cannot be denied by village notables or powerful patrons. The failure of all of these mechanisms means that the moral economy of the village will be destroyed, that exploitation will become not only unbearable but intolerable, and in such circumstances revolt is inevitable.

Such is the tale of moral economy as told by Popkin. As he admits himself many of the nuances are left out and individual theories blurred to produce a single theme. Still, the main elements - subsistence ethic, village insurance, and patrons - are clear. For purposes of this analysis another step is necessary - the formulation of an explicit theoretical statement which, based on Popkin's analysis, might read as follows: Peasant revolution occurs when the subsistence minimum is endangered and village security systems and patron-client ties destroyed by (a) ecological pressures (b) the demands of the state or (c) the growth of markets. The worst case for this model would be a situation in which a peasant found himself in a perilous natural environment confronted by a powerful state in the midst of an economic depression without patron or village to protect him. Indeed, this is precisely the situation Scott finds in the Vietnamese provinces of Nghe An and Ha Tinh during the Communist rebellions of 1930-31. Burdened with the worst conditions for agriculture in all of Vietnam in the best of times, the peasants of Nghe An and Ha Tinh, confronted with the worst times in the world depression of 1930 and finding that French colonial policy had brought the traditional village down around them, struck against the state by attacking tax collectors; against the landlord by burning land records, against the market by attacking granaries, and against the moral order by murdering mandarinal officials. They also organized the first People's Soviets in Vietnam and set in motion a revolutionary wave which, building slowly at first, swelled to engulf all of Vietnam in 1975. But this is another story. For Scott and other moral economists the peasant revolutionaries are looking back toward the solidarity of the traditional village not forward toward a new socialist order. If they bring about the latter in pursuit of the former this is simply one of many examples of the unintended consequences of human actions.

\section{Mill: Political Economy}

Political economy as developed by Popkin is based on two fundamental assumptions: (1) the social solidarity of the traditional village could not have 
been disrupted by the state, the market or nature because there was little social solidarity to begin with; and (2) the individualistic actors of the peasant village can only be united by individual incentives delivered by efficient political organizers. It may be the case, Popkin argues, that the peasant village was a corporate communal entity, but within its boundaries (typically a bamboo hedge in Vietnam) the appearance of solidarity often cloaked individual calculation and greed. True, all citizens participated in village affairs, but far from all villagers were citizens; taxes were levied on the village as a whole, but were rigged by village notables so that they fell regressively on the poor and the weak; insurance funds did work, but at a cost paid by the poorer villagers to the rich; communal land existed, but it was often arid or under water and good land was raffled off to the politically influential; ceremonial expenditures were heavy, but they solidified the control of a dominant political machine; village decisions were reached by consensus, but this reflected a fear of the dominant faction, not democracy; the rich loaned money to the poor but they expected a profit; patrons took as clients only the most servile and only when it increased their own influence. The colonial state and the market made all of these things worse; instead of destroying the village they tightened the control of the wealthy and politically influential, and increased the rewards of graft and the power of the ruthless. But before and after the coming of the colonial economy the village ran on self-interest, a divided collection of potatoes in a sack.

In such an atomized world collective appeals, revolutionary as well as conservative, find little response. Accordingly; the political leader must offer individual incentives such as lower rents, equitable taxation, fair land distribution, insurance that works, irrigation water, or the elimination (often physical) of the landlord; and, if he is to avoid the problem of the "free rider," must extend benefits only to those who support his program. It is helpful if the political organizer is efficient and honest; otherwise he will be seen as just one in a long line of corrupt village tyrants. In Popkin's analysis ideology is unimportant. Catholic priests, Cao Dai warlords, mad Hoa Hao bonzes, and Communist cadre all succeeded because they were honest, efficient, organized purveyors of individual incentives. Popkin's argument reduced to a single hypothesis might read as follows: Peasant revolution occurs when honest, efficient political entrepreneurs organize the delivery of valuable individual incentives to selected members of an atomized village. If political entrepreneurs more often succeed in non-traditional than traditional villages it is because both organizational effectiveness and opportunities for the delivery of individual incentives are greater in the former. Popkin notes that a subsistence crisis preceded the Nghe An-Ha Tinh soviets in 1930-31, but adds that an even worse crisis occurred at the turn of the century with no 
revolt. The difference? "By 1930 there were more than three hundred Communists ... actively working among the industrial workers of the area and urban labor organization was already making an impact."13 Popkin also notes another fact inconvenient for the moral economy theorists: most protests in the twentieth century in Vietnam occurred in the Mekong Delta of colonial Cochinchina where income and living standards were highest, and none in Tonkin, by far the poorest of the three colonial regions and the closest to the subsistence margin. The colonial region of Annam, almost as poor as Tonkin, was, except for Nghe An-Ha Tinh, generally quiet. Scott's strongest empirical case turns out to have been the exception rather than the rule in Vietnam. The Communists (and the Cao Dai and Hoa Hao before them) succeeded in the Delta because they had more resources to distribute in the form of selective incentives. There was nothing to redistribute in Annam and Tonkin except poverty.

\section{Marx: Class Conflict}

Popkin is correct in arguing that the Mekong Delta of colonial Cochinchina was the most rebellious area of Vietnam under the French and that the narrow coastal strip, most of which was included in the colonial administrative division of Annam, and the northern coast and Tonkin Delta (Colonial Tonkin) were generally quiet. Indeed, my own analysis of Vietnam began with a reconsideration of a 1967 RAND corporation report by Edward Mitchell which suggested that in the southern part of a divided Vietnam, the government of the Republic of Vietnam (South Vietnam) found its greatest support in regions of extensive tenancy, large estates, and export agriculture, all of which typify the Delta and that, by contrast, the Communists were strongest in areas of traditional village structure and minute owner-operated holdings in the Coastal Lowlands. ${ }^{14}$ Mitchell's analysis was used by Eric Wolf to support his contention that independent small holders, not sharecroppers, were the main carriers of revolution in Vietnam. The contrast between the Mekong Delta on the one hand and the Coastal Lowlands and Tonkin Delta on the other, or, to use the colonial nomenclature, between Cochinchina and Annam and Tonkin, distinguishes the moral economy predictions from those of both political economy and class conflict. On this specific empirical point Mitchell, Wolf, and Scott are almost certainly -wrong, as both Popkin and I have argued although Wolf disputes the clear-cut nature of the comparison and Scott did extend his argument to include the Delta protests of the 1930s (he did not include analysis of other movements in Vietnam). ${ }^{15}$ The Delta was more rebellious not only in the French colonial period but, as Bernard Fall had demonstrated, in the early post-independence period as well. ${ }^{16}$ This does not, however, necessarily 
imply that Popkin's political economy theory is correct. Considering much the same data on Vietnam but also substantial additional data from worldwide patterns of agrarian social movements I concluded that the key element of the Delta economy was its class structure, not its potential for selective incentives. In particular, I proposed that the well documented radicalism of the Delta was a result of class conflict between backward capitalists whose only capital was land and a rural semi-proletariat whose only remaining claim was to a share of the crop as a wage. The landlords, whom I called "noncultivators," relied on political influence to secure land and labor, lacked the resources to share their surplus with their workers, and refused any political compromise. The workers, whom I called "cultivators," severed from the conservative effect of the ownership of even small amounts of land, limited to improvement in their living standards only through group action, and dependent on the worker community for much of what the moral economists called social insurance, demanded radical change. The result was revolution. Indeed, this pattern appeared to be quite general, particularly in agricultural export sectors organized in systems of decentralized sharecropping such as those in the Delta or in colonial estate agriculture employing extensive amounts of migratory wage labor. This analysis leads then to the third and final proposition about the causes of revolution in Vietnam, this one my own: " $A$ combination of noncultivators dependent on income from land and cultivators dependent on income from wages leads to revolution. Such a combination of income sources is typical of sharecropping and migratory labor estate systems." 17 The empirical prediction about the area of greatest revolutionary activity (the Delta) made by this theory is, of course, the same as that made by Popkin. Therefore, although the evidence from Vietnam seems to provide more support for the political economy or class conflict perspectives than it does for moral economy, this evidence alone does not distinguish between the two "economic" theories. The regional distribution of revolutionary activity in Guatemala, the second case of peasant revolution, does permit such a distinction. The predictions of the three theories about the location of revolutionary events in Guatemala are distinct and in general support the class-conflict perspective more than either of the other two.

\section{Guatemala: Peasant Unions, Military Men, and Guerrilleros}

In October of 1944, Jorge Ubico (1931-1944), the last in a long line of military dictators, was overthrown and the Guatemalan revolution began. It has not yet ended. The fall of Ubico and the election of Juan José Arévalo began a brief era of democratic reform and popular mobilization. But this was abruptly halted by the flight of Arevalo's successor, Jacobo Arbenz 
Guzmán, and the collapse of his government in response to an invasion by Guatemalan exiles from neighboring Honduras. The exiles were organized by the United States Central Intelligence Agency but led by a Guatemalan General, Carlos Castillo Armas. Castillo Armas, who was assassinated shortly after assuming power, and a new line of military and civilian dictators have tried, through a combination of medieval barbarity and modern technology, to contain the popular mobilization begun by Arévalo and Arbenz. Despite the slaughter of perhaps 50,000 of their opponents in the years since $1954^{18}$ they are at this writing as far from their goal as ever. The Guatemalan revolutionaries, like the Vietna mese, show an amazing persistence, although thus far they have not acquired the military potency of the North Vietnamese infantry.

Although the "terrorists" who have run the Guatemalan government since the fall of Arbenz have not lacked urban opponents, Guatemala, like Vietnam, is an agricultural country and it is rural revolutionaries and their leaders who continue to constitute the greatest threat to the generals' counter-revolution. Rural mobilization has taken place in three distinct episodes: the peasant union movement, 1952-1954; the guerrilla movement, 1962-1967; and the guerrilla movement at present. The Agrarian Reform Laws of 1952 issued in a brief period of intense union activity among the peasantry and led to the formation of some 1,700 peasant unions by 1954 and their integration in the National Peasant Federation of Guatemala (CNCG). The Federation, with a block of perhaps 150,000 votes, formed a decisive political force in democratic elections. ${ }^{19}$ The CIA-sponsored invasion ended both the unions and the lives of many of their organizers. The CIA involvement in Guatemala was, however, a decidedly mixed blessing even for the military officers themselves, and the use of a coffee finca at Helvetia de Retalhuleu as a training base for exiles for another CIA invasion, this time at the Bay of Pigs, split the military and led to an abortive coup attempt on November 13,1960. The coup failed but a small number of officers led by Luis Augusto Turcios Lima and Marco Antonio Yon Sosa retreated to the wilds of eastern Guatemala and organized a guerrilla war. Beginning in 1962 it gained considerable momentum, but it was crushed in a massive counterthrust in 1967 by still another military officer, Colonel Carlos Arana Osorio. $\mathrm{He}$ earned the nickname the "butcher of Zacapa" for slaughtering 15,000 peasants to eliminate perhaps three hundred guerrillas. ${ }^{20}$ In 1967 , their leaders dead or in hiding, their eastern base liquidated, the guerrillas seemed defeated. But by 1980 a reorganized guerrilla movement fielding four separate but loosely coordinated commands was posing the most serious threat the generals had faced since the fall of Arbenz. In 1966 Yon Sosa told Adolfo Gilly that in two and a half years of war his guerrilla front had 
inflicted 142 deaths on the military and police. ${ }^{21}$ On May 16, 1981 the Organization of the People in Arms (ORPA) claimed that in a single action, a "claymorazo" or ambush with Claymore mines, it had annihilated a military convoy killing fifty-nine soldiers and wounding six, and this was not an isolated incident. ${ }^{22}$ Regis Debray had said that the Guatemalan guerrillas of the sixties had achieved the greatest mass support of any movement in Latin America, with the possible exception of Colombia. ${ }^{23}$ The strength of the current Guatemalan guerrilla movement seems an order of magnitude greater.

\section{The Ecology of Rural Protest}

As was the case in Vietnam, rural protest in Guatemala follows clear-cut patterns of geographical concentration, although, unlike Vietnam, the focus of conflict shifts over time. Each of the three movements since the Arbenz period had a different regional and ecological base. The areas of concentration reflect both the nature of the movements and the regional specialization of Guatemalan agriculture. The major ecological regions of Guatemala, as they are generally described are shown in Map $1 .{ }^{24}$ The North and the Caribbean Lowlands, frequently discussed together, are regions of forbidding jungle, lowland terrain, sparse population and casual swidden cultivation. They have been largely empty since the fall of Maya civilization in the ninth century A.D., although recently the North has attracted considerable attention as a possible site of a large petroleum deposit. The heart of the current Indian population, however, is in the Central Highlands, shown as the West in Map 1, a rugged, mountainous area with cultivated valleys and barren high plateaus. This is a region of microscopic subsistence holdings, minute parcel subdivision, intensive cultivation, primitive agricultural technology, and acute overpopulation. It is also a region of grinding poverty, backbreaking toil, starvation, and death. It is not uncommon to see a man laden with a burden of fifty pounds or more walking beside a horse lightly laden or carrying nothing at all. The horse is valuable; the man, expendable. Every available inch is cultivated, in corn at lower altitudes and wheat at higher ones, and it is not uncommon to see the roots of corn plants protruding through eroded overhangs beside roads, or corn growing on slopes that appear accessible only with the aid of mountaineering equipment. In Vietnam, only in Tonkin and the poorest areas of Annam did one find this desperate overcultivation and degrading substitution of human for animal labor.

Agriculture in the Central Highlands cannot support the population. In some areas virtually all adult males depart to work in the Pacific Coastal 


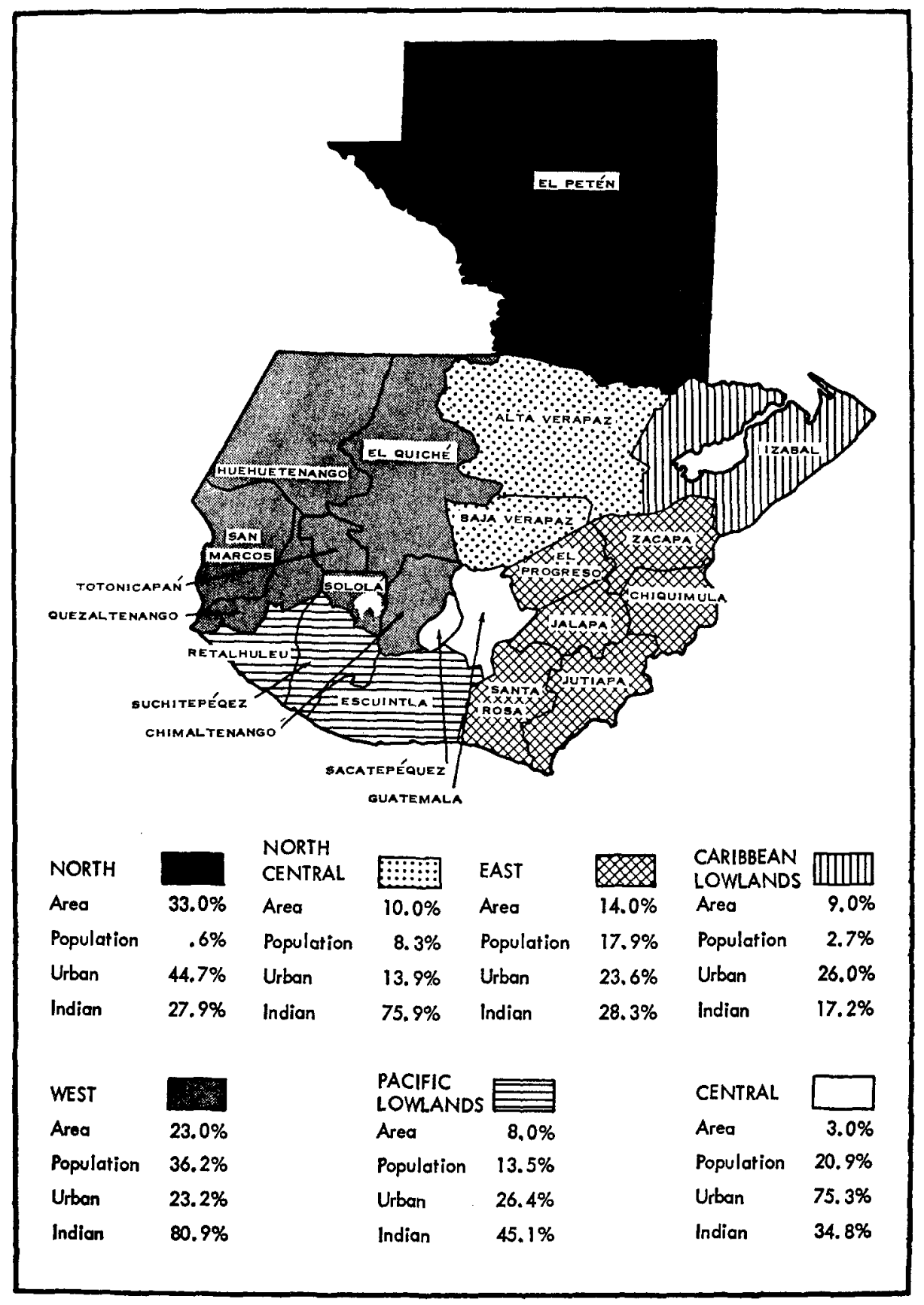


Lowlands for six months of the year. The Lowlands departments of Retalhuleu, Suchitepéquez, and Escuintla are major destinations for highland migrants and it is here that most of Guatemala's export crops are produced, and these crops are the Guatemalan economy. The nature of coastal agriculture, as West and Augelli have pointed out, depends on altitude. ${ }^{25}$ The lowest altitudes, tropical in climate, were formerly almost exclusively pasture and as late as 1960 were underdeveloped because of problems of transportation, irrigation, and disease. But since that time pesticides, highways, and bank loans have made possible a massive expansion of cotton production and the lower coast is now the most dynamic agricultural region in Guatemala. ${ }^{26}$ In 1973-74, for example, the department of Escuintla alone accounted for 68.5 percent of total Guatemalan cotton production. ${ }^{27}$ At slightly higher altitudes sugar cane, bananas, cardamon and other crops are grown. Still higher, at altitudes from 500 to 1500 meters, is Guatemala's coffee piedmont which stretches through the southern coastal provinces and into the coastal extensions of the highland departments of Quezaltenango and San Marcos. This is the oldest region of export agriculture in Guatemala. Coffee cultivation began on a large scale as early as $1880^{28}$ and was, until the sixties, the only major producer of export earnings and the only major consumer of migratory labor from the highlands. The principal producing departments in the coastal coffee piedmont, ranked by production in 1974, were San Marcos, Retalhuleu, Quezaltenango, Santa Rosa, Guatemala, and Chimaltenango. ${ }^{29}$ It should be noted that in all southern and some western departments, geography and political divisions do not coincide. Many of these departments, such as Suchitepéquez, have zones in the Central Highlands as well as in the Coast and Coffee Piedmont. Coffee is also produced in a second distinct zone of relatively poorer soil but abundant and virtually cost-free labor in the north-central province of Alta Verapaz. In both areas coffee is produced almost entirely on large estates by a labor force divided between resident tenants and harvest migrants. The estates are owned by the ladino (the Gualtemalan term for fictive Hispanic descent) oligarchy and worked by Indian labor.

Since the Central Region is largely urban, the remaining agricultural zone is found in the Eastern Highlands (the East in Map 1). As the data in Map 1 indicate, in comparison to the Central Highlands and the Verapaz, the population is predominantly ladino rather than Indian and living standards are somewhat higher. Overpopulation is not as serious as in the Highlands, there are considerably more middle-sized holdings, and agriculture is productive enough to eliminate the need to migrate to work in the export sector. In the Eastern Highlands animals rather than people carry the burdens. Although most agriculture is subsistence, the acute agrarian crisis of the Highlands is largly absent in the East. 
As the data in Table 1 indicate, the three major agrarian social movements which make up the rural phase of the Guatemalan revolution were each concentrated in a different ecological region. Column 4 in Table 1 shows the number of peasant unions in each province in 1954 as reported by Pearson..$^{30}$ The distribution of coffee production was roughly the same in 1954 and 1974, with the notable exception of Retalhuleu which was not a major producer in the fifties. With a few exceptions unions follow the coffee harvest. San Marcos, the largest producer, has the most unions. Quezaltenango, Chimaltenango, Santa Rosa, and Guatemala in the southern Coffee Piedmont and Alta Verapaz in the North Central producing area all have large numbers of unions. Only Huehuetenango and Escuintla have unions and little coffee and only the former is an exception. The Escuintla unions were on sugar and banana plantations. As Pearson notes, “. . . it is probably not unreasonable to assume there are at least 1,500 active unions in the CNCG based principally on the 1,408 large plantations with over 100 inhabitants on them or the 1,736 plantations producing over 200 bags of coffee per year." 31 The Central Highlands, except for Huehuetenango, were quiet during the period of peasant mobilization under Arbenz. The plantation proletariat of Escuintla, particularly the banana workers, and the tenants of traditional coffee estates, were the principal supporters of the CNCG.

The rebels of the sixties did not, however, build on this peasant base in the Coffee Pied mont but rather chose the remote Sierra de las Minas range in the East largely, it appears, for military reasons. The military rebellion of November 13, 1960 involved two garrisons: Matamoros outside Guatemala city and Zacapa in the military district of the same name. The rebels also took control of the banana port of Puerto Barrios in Izabal until they were dislodged by troops and air strikes flown by Cuban exiles from the training base at Retalhuleu. It was "a typical nationalist revolt"32 and the rebel officers, who had no plans to arm the peasantry, seem to have been convinced to continue their struggle by their outlaw status and, according to Gilly, an outright request from eight hundred Zacapa peasants for arms and leadership. ${ }^{33}$ When, after temporary exile, the rebel officers returned to Guatemala to take up the struggle, it was natural that they would return to Zacapa and Izabal, departments where they could count on peasant support and, at least initially, unenthusiastic military opposition. The mountains and jungles of the east also provided favorable terrain for guerrillas, but there is no scarcity of such terrain in Guatemala. As Gilly reports: "In February 1962 under the name of Movimiento Guerrillero Alejandro de Leon 13 de Noviembre, Yon Sosa's forces began the struggle in the Mountains of Izabal, in the Sierra de las Minas." ${ }^{34}$ The Sierra de las Minas are located in the area surrounding the intersection of the departments of Zacapa, Izabal and the 


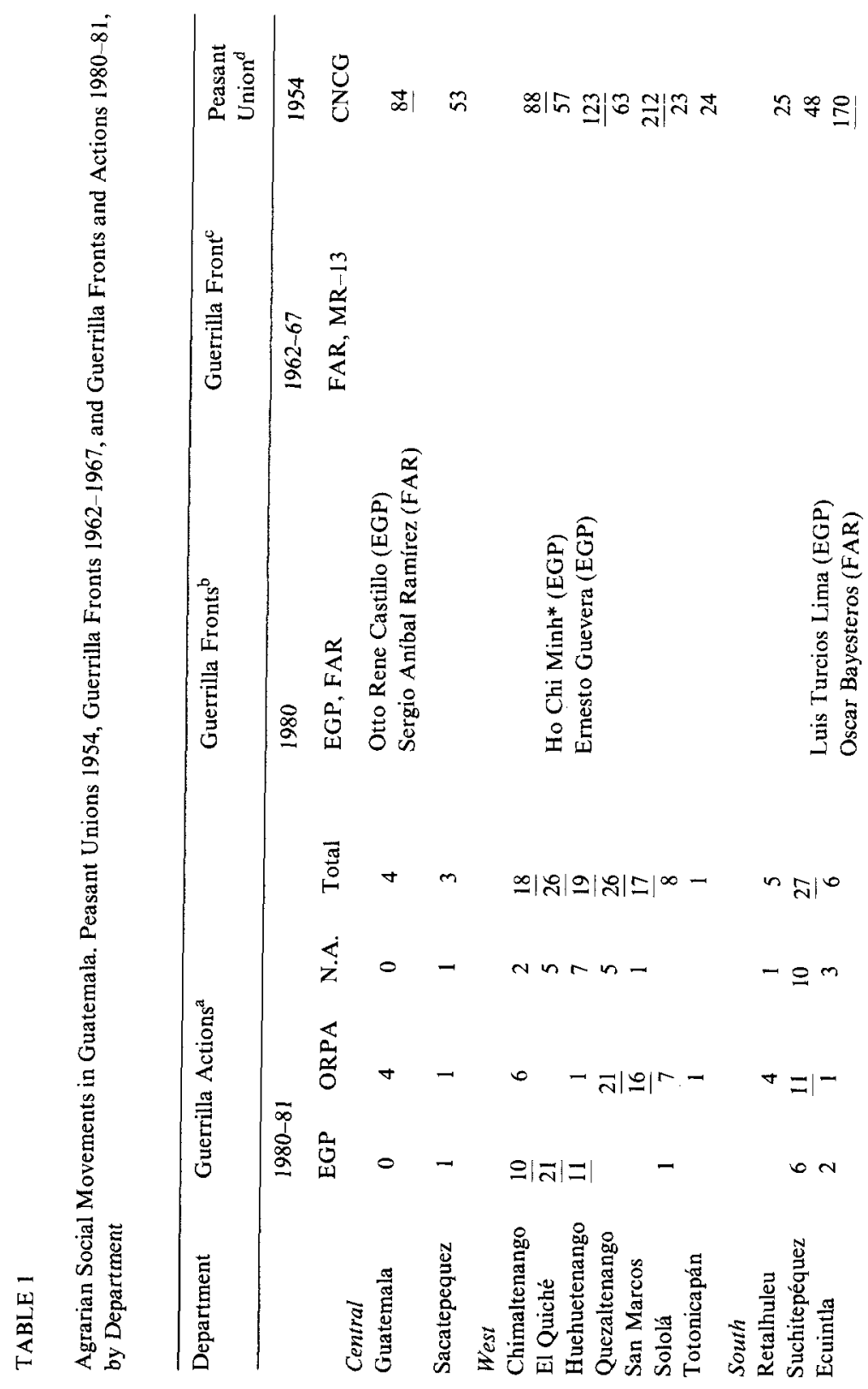




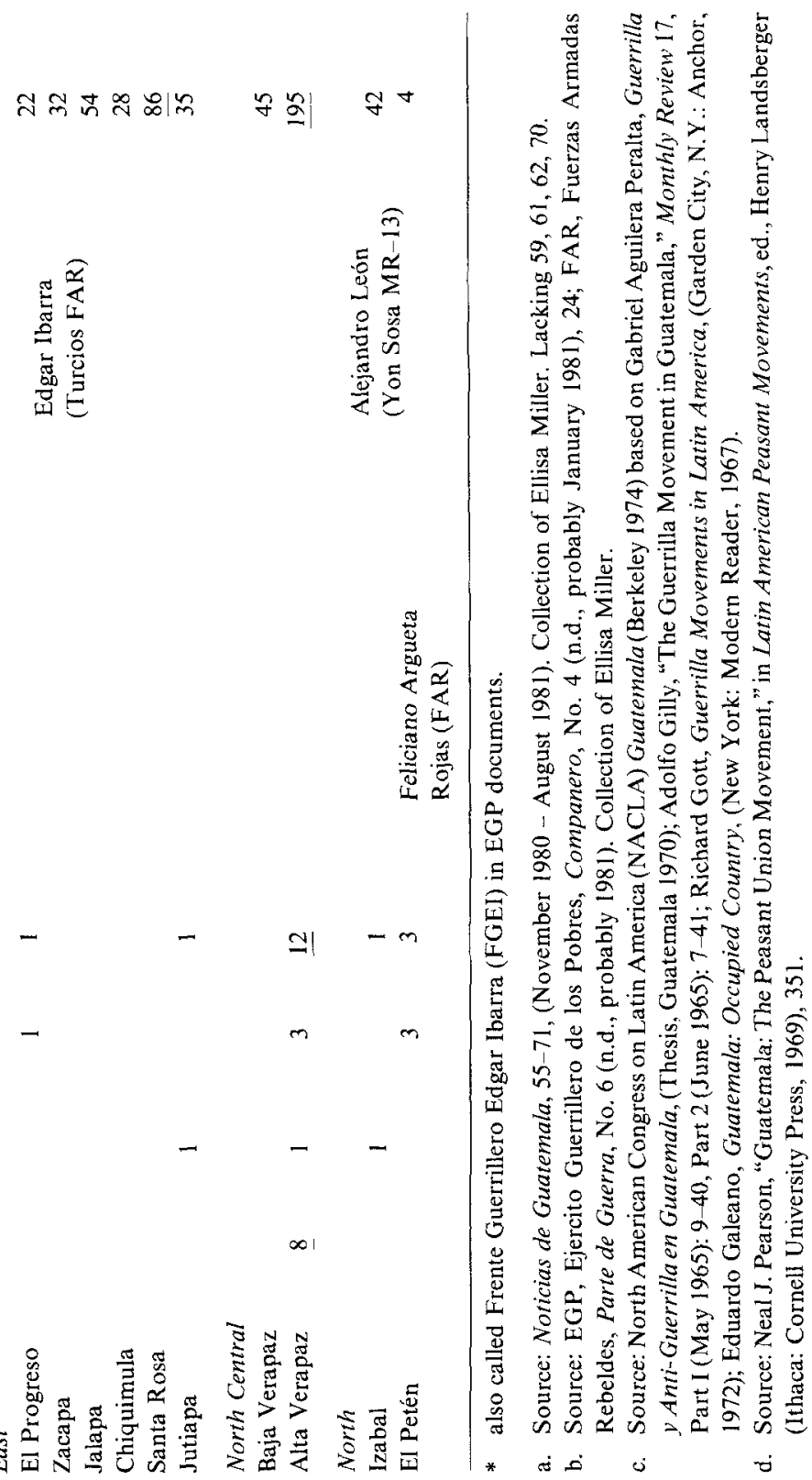


southern extension of Alta Verapaz; guerrilla units operated in all three areas. ${ }^{35}$ As Table 1 indicates, however, there were two principal guerrilla fronts: the first, the original Alejandro Leon front, led by Yon Sosa and named after one of the military rebels killed before the beginning of the guerrilla war. Yon Sosa's organization, called MR-13 after the date of the military rebellion, first allied and then split with a broader protest organization called the Rebel Armed Forces (FAR) initially dominated by the Guatemalan Communist Party (PGT). FAR established a second major guerrilla foco, the Edgar Ibarra front, named after a student leader killed in Guatemala City, and led by Turcios Lima, in Zacapa. Despite their differences, including a Trotskyist preference for mass insurrection in MR-13, both organizations, although originally led by nationalist military officers, were both revolutionary and socialist. Yon Sosa makes clear the ideology of his organization in an interview with Gilly in 1964:

\section{How did you all become socialists?}

While we were dodging bullets. It's impossible to fight for very long, side by side with peasants, and not become a socialist. An armed revolution must become a socialist revolution. Which countries, similar to ours, have been able to emerge from backwardness? Cuba, China, North Vietnam, North Korea - they have all taken the socialist path. A backward country cannot advance along the capitalist path, and there is not a third alternative. All you have to do is look around and see what's happening in the world. How could we not be for socialism. ${ }^{36}$

The reference to Vietnam (italics mine) was not incidental since Vietnam had been the topic of an extended discussion among Gilly, Yon Sosa, and other guerrillas the night before. Yon Sosa went on to say that both Guatemala and Vietnam were engaged in a common struggle to overthrow imperialism ("a bunch of bastards") and were part of a world-wide military offensive uniting all socialist states. According to NACLA, "By mid-1966 the FAR had influence over a wide area in Izabal, Zacapa and Alta Verapaz, and in some villages virtually coexisted with the local authorities," and MR-13 had a similar influence in the area around Izabal. ${ }^{37}$ The nationalist military officers had attained this following, as Gilly makes clear, by adapting their ideology to the desires of the peasants and rural laborers. ${ }^{38}$ Otto Rene Castillo, one of Guatemala's greatest poets, who joined FAR under the command of Turcios Lima in that same year, 1966, puts it best:

\footnotetext{
Por ello pido que caminemos juntos. Siempre con los campesinos agrarios y los obreros sindicales, con el que tenga un corazón para quererte.
} 
For this I say let us walk together, always

with the agrarian peasants

and the union workers

with he who has a heart to love you.

Let's go, my country, 1 will go with you. ${ }^{39}$

But 1966 was the guerrillas' high water mark. Turcios Lima was killed in an automobile accident in Guatemala City on October 2, 1966. Colonel Arana's counter-insurgency campaign in the East destroyed the Edgar Ibarra front in 1967 and Turcios's successor, Camino Sanchez, was captured and executed in Guatemala City in 1968. The army also crushed the Alejandro León front of MR-13, driving Yon Sosa, hunted and alone, to seek refuge in Guatemala City. In March 1967 Otto Rene Castillo was captured, tortured for four days, and burned alive. The guerrilla movement of the sixties was over.

Neither Turcios's FAR or Yon Sosa's MR-13 ever successfully extended their operations outside their Sierra de las Minas base in Zacapa and Izabal. MR-13 planned to organize coffee workers ${ }^{40}$ but apparently this strategy was never carried out. FAR also organized resistance zones in the Western Highlands near the coast in the departments of Quezaltenango and San Marcos, and these fronts, although never as active as the East, survived the "Butcher of Zacapa" and were still active in the early seventies. ${ }^{41}$ Attempts to extend the guerrilla war to the Central Highlands were, however, a disaster. Turcios Lima describes an attempt in November 1962 to organize a guerrilla front in Huehuetenango:

It (Huehuetenango) is a very mountainous yet densely populated area. The leaders of the movement had made no political preparations; they barely knew the terrain and they had no support from peasant organizations. They went round and round in circles, vainly trying to explain in lightning meetings what they were fighting for. A setback. They were all captured and shot. . . ${ }^{42}$

Only in the East did the guerrillas gain any significant support. In the other major ecological regions of Guatemala - the Central Highlands, the South Coast, and the Coffee Piedmont - they were, with the exception of minor FAR activity in Quezaltenango and San Marcos, completely unsuccessful.

In 1975 guerrilla war came to the Central Highlands. In the spring of 1975 guerrillas from the Poor People's Guerrilla Army (EGP), a new organization founded in 1973, shot Luis Arenas, the "tiger of Ixcan," an unpopular landowner, as he watched his administrator give his workers their meager pay. The following day the guerrillas returned and occupied Ixcan and other towns in Huehuetenango. ${ }^{43}$ Many such incidents followed and by 1980-81, 
as the data in Table 1 indicate, guerrilla actions had engulfed the entire Central Highland region and had extended to the South Coast and Coffee Piedmont as well. But the old areas of FAR and MR-13 strength in Zacapa and Izabal were almost entirely quiet.

The data in the first column of Table 1 were computed by the author from the "Sintesis de Noticias" section of Noticias de Guatemala, a publication of the Democratic Front Against Repression which is a broad-based opposition group not limited to the guerrilla organizations. The location of the guerrilla fronts as listed in column 2 was derived from press releases and other publications of the guerrilla organizations themselves. In 1974 there were four major guerrilla organizations; they agreed in 1982 to coordinate their formerly separate commands. Two of these organizations, the Poor People's Guerrilla Army (EGP) and the Organization of the People in Arms (ORPA), were new organizations although, in the case of ORPA in particular, seem to have built on the organizational work of FAR. FAR itself reorganized and shifted its activities to the South Coast and the jungles of the North. The Guatemalan Communist Party (PGT) also launched a guerrilla campaign although their activities were concentrated in urban areas.

Table 1 shows the activities of all four organizations reported in Noticias from November 1980 to August 1981, although all but two of the actions carried out by groups whose identity was given were by the EGP and ORPA. This should not, however, be taken as an indication of relative activity since Noticias includes both actions culled from the Guatemalan press, in which the identity of the guerrillas, often described as bands of heavily armed men, is not given, and press reports of the guerrilla organizations themselves. Almost all the latter communications are from EGP and ORPA; actions reported in Parte de Guerra, the war report of FAR, do not appear in Noticias. Communications, needless to say, among these clandestine groups are difficult and the government does its best to disrupt them, so it is not surprising that some groups appear to have better communications channels than others. Noticias does report completely and accurately press releases which I have in my possession from both ORPA and EGP. For example, the EGP press release, Parte de Guerra of July 24, 1981, lists 24 separate actions commemorating the second anniversary of the Nicaraguan Revolution of July 19, 1979. Every one of these actions is correctly reported and accurately summarized in Noticias. Similarly, an ORPA press release of April 13, 1981 (Comunicado a la Prensa, Radio y Televisión) reports a series of actions which also are accurately summarized in Noticias. Since the Guatemalan press is heavily if selectively censored and the Army secretive, these may be the best sources available on the location of the contemporary guerrilla movement. 
Table 1 reports only those actions which involve groups, whether or not they are explicitly identified as guerrillas, who engage in armed action against either military or police forces. This includes attacks on police substations and barracks as well as on mobile units; attacks on economic targets such as plantations and warehouses; and on elements of the infrastructure such as bridges, rail lines, buses, trucks, and oil rigs. It also includes armed actions in which violence does not occur if it involves groups of people initiating and receiving the action. The most frequent action of this type is the armed occupation of a town or farm for purposes of holding a political meeting. It excludes assassinations, which are very numerous (they are called "ajusticiamientos," "executions," in Noticias) unless they are part of an attack on a group of government, police, or military officials, and bombings, unless part of a general attack by a group. In the latter two cases the responsibility for the action is often difficult to assess and such actions may also be carried out by lone individuals far from the guerrillas' base of operations. It should be noted that only major actions are included in Table 1 : if assassinations and bombings were included the number would have been considerably larger. Table 1 is limited to actions occurring outside of Guatemala City and its immediate suburbs, such as Amatitlan, but includes any action occurring outside of the Central Region even if it occurs in what passes for a city in rural Guatemala. Actions reported together but occurring in different departments have been counted separately. Most of the actions fall into two general types: (a) ambushes of police and military units (emboscadas) and attacks on police stations and military barracks (ataques); (b) military occupation of towns and farms and the holding of mass meetings, distribution of propaganda leaflets, and recruitment of supporters (called "toma de lugares," "seizure of places," in Noticias), and destruction of agricultural machinery, buildings, vehicles, and other elements of the economic infrastructure, often in conjunction with an armed occupation (sabotaje). Below are translated descriptions of actions of each type as they appeared in Noticias and the original guerrilla press release.

A: Ambushes and Attacks. EGP: Parte de Geurra, July 24, 1981. At 9:45 hours at kilometer 162, jurisdiction of Cuyotenango we carried out a harrassing ambush against a military convoy composed of one truck with 40 soldiers and one jeep. In the operation we detonated 2 claymore mines causing 9 enemy deaths and an indeterminate number of wounded.

Noticias, August 20, 1981.

\begin{tabular}{|c|c|c|c|c|}
\hline Type of Action & Place & Org. & Result & Source \\
\hline $\begin{array}{l}\text { Harrassing Ambush } \\
\text { against a military } \\
\text { convoy. Claymore }\end{array}$ & $\begin{array}{l}\text { Km. } 162 \text { jurisdic- } \\
\text { tion of Cuyotenango } \\
\text { Suchitepéquez }\end{array}$ & EGP & $\begin{array}{l}9 \text { soldiers } \\
\text { dead and an } \\
\text { indeterminate } \\
\text { number wounded }\end{array}$ & $\begin{array}{l}\text { Press } \\
\text { Release } \\
7 / 24 / 81\end{array}$ \\
\hline
\end{tabular}


B: Occupations and Sabotage. ORPA: Comunicado a la Prensa, April 13, 1981. Tuesday April 7. ORPA fighters, in the municipality of Colomba, Quezaltenango, carried out a substantial operation of military occupations which lasted from 5:00 A.M. to 15:00 P.M. At 5:15 A.M. they occupied the Mujuliá estate and at 6:00 A.M. the estate of Culpan, where they communicated to the workers the message of the revolution and the accomplishments of the popular revolutionary war. At 7:00 A.M. they captured through military action, the municipal capital of Colomba where the day before the government had forced a demonstration of support for the army and regime by threatening the inhabitants. The agents of the substation of the national police were forced to withdraw and all the arms of the garrison were recovered and, according to the policy of ORPA, the lives and finances of the police were respected. Through the local facilities of TGAC an ORPA fighter transmitted a revolutionary message for ten minutes and a meeting with the population was held in the central park. In the remainder of the action our forces occupied the Transito-Bolivar and Providencia Fernandez estates withdrawing without difficulty at 15:00 hours.

Noticias, May 4, 1981, 19.

\begin{tabular}{|c|c|c|c|}
\hline Type of Action & Date & Place & Org. \\
\hline \multicolumn{4}{|l|}{ Result } \\
\hline $\begin{array}{l}\text { Seizure of places } \\
\text { and meetings }\end{array}$ & $4 / 7 / 81$ & $\begin{array}{l}\text { Municipal Capital of } \\
\text { Colomba, Quezaltenango, } \\
\text { Radio TGAC local } \\
\text { facilities Estates of }\end{array}$ & $\begin{array}{l}\text { ORPA Distribution of a } \\
\text { great quantity of } \\
\text { propaganda. Transmis- } \\
\text { sion of revolutionary- }\end{array}$ \\
\hline Source & & Mujuliá Culpán, & messages. Recovery of \\
\hline Press Release & & Tránsito Bolivar and & all arms of the garrison \\
\hline $4 / 13 / 81$ & & Providencia Fernández & \\
\hline
\end{tabular}

The first of these two actions is a typical "claymorazo" or ambush with claymore mines, although the guerrillas distinguish two types; harrassing ambushes like this one, and ambushes of annihilation in which the intent is to completely eliminate the opposing force. The ORPA occupation of a municipal capital and several nearby estates is an example of what has come to be called "armed propaganda" and was one of the most common guerrilla actions both now and in the sixties. The actions reported in Noticias are somewhat more likely to be ambushes or attacks on police or military installations than occupations and sabotage, although many occupations may not be reported in the press where Noticias gets at least some of its information. The two best-covered guerrilla organizations also differ somewhat in the ratio of the two types of actions, with EGP relying more on military actions (forty ambushes and attacks versus twenty occupations and 
sabotage actions), and ORPA slightly more on armed propaganda (fortythree ambushes and attacks versus thirty-three occupations and sabotage actions), but clearly the tactics of both are very similar.

The regional distribution of actions by ORPA and EGPdiffer more markedly. The largest number of EGP actions (twenty-one) occurred in El Quiché which according to guerrilla sources, is the location of the oldest EGP guerrilla organization, the Ho Chi Minh front (also called the Edgar Ibarra front in some EGP press releases). The next most active is the adjacent department of Huehuetenango, the location of the EGP's Ernesto Guevara front. Chimaltenango, at the southern extension of the Ho Chi Minh front, is also the site of many EGP actions. It is clear that the core of EGP strength is the Maya Quiché region of the Central Highlands. The EGP also opened its newest front (Luis Turcios Lima) in the South Coast department of Escuintla and has also been active in the adjacent department of Suchitepéquez.

ORPA, which had organizational links to the old FAR focos in Quezaltenango and San Marcos, has greatly expanded activity in these two departments and in adjacent Sololá around Lake Atitlán; it has also operated in the southern portions of Chimaltenango while the EGP controls the north. Like the EGP, ORPA is also active on the south coast, particularly in Suchitepéquez, and examination of the municipal location of ORPA actions indicates that its activities cross all three of the department's ecological zones, although tending to concentrate in the Central Highlands' municipalities close to Lake Atitlán.

Actions by groups identified in Noticias follow approximately the same general distribution as those of ORPA and EGP, so it is reasonable to assume that many of these actions could be attributed to these organizations if more information were available. Both organizations have also been active in Guatemala City and the EGP's Otto Rene Castillo front operates here, but these actions have been excluded from Table 1 because of the restriction of the population to rural events. The new FAR has, according to its publication Parte de Guerra, been active in two distinctly different regions, the remote Peten and the south coast department of Escuintla. Its tactics are much the same as those of the two better described guerrilla organizations.

The most striking difference between this pattern of action and the earlier efforts of FAR, MR-13, and the CNCG is the mobilization of the Central Highlands. Huehuetenango, where the original military rebels failed so miserably, is now a center of rebellion. So is adjacent El Quiché which is engaged, as an American embassy spokesmen told the author in August 
1980, in "a small scale civil war." That portion of the Highlands not organized by EGP is controlled by ORPA which has attained success here never reached by the early FAR attempt in the same region. Only FAR remains in the jungle, but even this organization has abandoned its original eastern base and shifted its operations to the even more inaccessible Petén. Both ORPA and EGP have operated in the Coffee Piedmont but this does not seem to be their central focus as it clearly was for the CNCG. Both ORPA and EGP are attempting to extend their operations to the south coast, particularly in Suchitepéquez. But the Central Highlands are clearly their base of operations. In summary, each movement has a distinct regional base: the CNCG in the Coffee Piedmont, the FAR and MR-13 in the Eastern Highlands, and EGP and ORPA in the Central Highlands.

The change in the regional base of the guerrillas does not seem to reflect simple changes in guerrilla strategy but rather far-reaching changes in the structure of Guatemalan agrarian political economy and social structure. These changes were particularly dramatic in the Central Highlands and created the conditions for the guerrilla successes of the last year. The starting point for these changes was, as was the case in Vietnam, the traditional peasant subsistence village. Indeed, if one reads the traditional ethnographic literature on peasant communities written before 1970 the village social organization sounds much like the traditional Vietnamese village. ${ }^{44}$ Wagley puts it best:

\footnotetext{
At that time (1937) the Indians of Santiago Chimaltenango seldom acknowledged, and most did not even know that they formed a segment of the nation, ... They considered themselves as Chimaltecos, not Guatemaltecos. They respected their own civil religious officials selected by the Elders (Los Principales). They considered themselves "muy buen católicos" (very good Catholics) - by that term they meant a firm belief in the Saints as local deities, the guardian spirits of the mountains, and the ancestors as supernaturals. They evoked these supernaturals through the power of their own rituals which involved prayers led by their native shaman priests and offerings of incense soaked in turkey blood. Such communities were "localocentric," that is, united against outsiders, non-Indian and other Indians alike, to the extent of refusing to sell land within their territorial boundaries to outsiders. They were endogamous and closed communities and through their localocentrism they had maintained their identity despite exploitation and domination by Spanish colonial and Republican rule for four centuries. ${ }^{45}$
}

The civil religious hierarchy, the consensual rule of the elders, the cult of the guardian spirit, the integrating power of ritual, the corporate identity, the communal land ownership, the strict closed endogamy, the collective resistence to exploitation will all be familiar to students of Vietnamese peasant communities or indeed to students of any peasant communities. There is something in the traditional literature for political economists too; it was in Panajachel, Sololá that Sol Tax found that rational calculation toward small gain that caused him to refer to its citizens as "penny capitalists." 46 
Things have changed in Huehuetenango, where Wagley's village was located, and indeed, his intent in the passage quoted above is to underscore just how much they have changed. On July 19 of this year a detachment of soldiers entered another Huehuetenango village, San Miguel Acatán, not far from Wagley's Santiago Chimaltenango. According to a statement by FP-31, an opposition political group:

The people organized to defend themselves with sticks, stones and machetes. A fierce and unequal battle took place from early morning until mid-afternoon, with the military using a helicopter and a plane to strafe and bomb the population. An estimated $150-300$ persons were killed, including children, men, women and aging villagers.

"The distance which separated the two forces was only a few meters," stated the FP-31. "The soldiers yelled 'Long live Lucas!' The people cried 'Long live the people and the revolution!'”47

The EGP had held an armed propaganda meeting in San Miguel Acatán in early April 1981 and, jud ging from the villagers' reactions to the troops, must have received a warm welcome. ${ }^{48}$ Presumably the soldiers were aware of this when they went to San Miguel. From "buen católicos" to desperate revolutionaries in a generation.

There is considerable evidence that these changes are very recent, dating from the late sixties or early seventies, and that the Central Highlands would not have supported the guerrillas earlier no matter how effective or well-informed about local conditions they had been. In 1962 Turcios Lima's guerrillas found no response when they tried the same tactic, armed propaganda, that the EGP has been practicing successfully all over Huehuetenango since 1975. The FAR guerrillas found no peasant organizations because no peasant organization existed. Tragically, they had arrived a scant decade too soon. In 1966-67, for example, Colby and van den Berghe (1969) studied the Ixil region of El Quiché, the source of many of the peasants who died in the sit-in at the Spanish embassy in January 1980, and one of the areas where the EGP has been most active, particularly in the towns of Nebaj, Chajul, and Cotzal where Colby and van den Berghe were doing their interviewing. ${ }^{49}$ The government has been sufficiently concerned about the guerrillas' support in this area that it has carried out massacres of unarmed peasants in both Nebaj, in March 1980, and at Cotzal, in July 1981..$^{50}$ Yet Colby and van den Berghe could write, and there is no reason to doubt them, that in 1966-67 ". . . the Ixil community itself exhibits considerable group solidarity. This is clearly illustrated in the recent revival of traditional religion, resentment of the catechists, and recapture of political offices by the traditionalists." ${ }^{11}$ The "buen católicos" of the civil-religious hierarchy with their turkey blood and mountain spirits were holding off catechists who were trying to convert the peasants to Catholicism. Where Catholic priests failed, Marxist guerrillas preaching Trotskyist world revolution could hardly be expected to succeed. 
But in Aguacatán, less than ten miles from Nebaj, Douglas Brintnall found that by 1975 the village had reached ". . . some kind of critical point at which a major social transformation occurs." ${ }^{2}$ The traditionalists had been routed, the civil religious hierarchy of Aguacatán had collapsed, and ancestor worship was as dead as the kinsmen it celebrated. In 1970, for the first time, an Indian was elected mayor and responded by throwing the ladinos out of local offices, precipitating a confrontation with the local military commander and a minor skirmish with the army. Although the FAR guerrillas found no peasant organization in 1962, had they returned in 1975 they would have found that a hugely successful one had just been established. On March 2, 1981 an Army convoy moving through Aguacatán was caught in a "claymorazo" sprung by the EGP. The army unit was wiped out with thirty dead and twenty wounded..$^{53}$ Revolutionary change in Aguacatán had been terrifyingly compressed into less than a decade.

Similar changes were apparently taking place elsewhere in the Highlands in the same decade. Robert E. Hinshaw surveyed selected villages on Lake Atitlán in 1965 and again in 1974 as part of his restudy of Tax's Panajachel. In Santa Maria Visitación the cofradias, religious festivals led by the traditionalists, were disbanded in 1963 and by 1968 the politicized villagers were lobbying the government in Guatemala City for a hydroelectric project. In Panjachel itself Hinshaw found that in 1974 "the cofradias were still staffed but with increasing difficulty," and that, "Panajacheleños participated more actively in the election campaigning that they had the previous decade." ${ }^{54}$ In San Andreas Semetabaj, also on the lake, Kay Warren found that by 1971 the previously politically passive Indians of what was an unusually wealthy community by Highland standards had staged a strike by refusing to enroll their children in school unless a dispute with the ladinos over payment for school lunches was settled. ${ }^{55}$ Here too the civil-religious hierarchy was losing ground to a reform-oriented missionary group.

The guerrillas' success in the Central Highlands reflects deep-seated changes in the social structure of rural Guatemala which created the possibility for an Indian political mobilization. The guerrillas' operations had shifted because the political environment in the Highlands had changed. The location of the three movements as well as the successes of the EGP and ORPA in an area where FAR had failed, raise fundamental question for theories developed in Vietnam. What accounts for the shift in location and the radical transformation of the Highlands? There are of course three distinct answers. 


\section{Guatemala: Moral Economy and Political Economy}

\section{Moral Economy}

The concentration of the contemporary guerrilla movement in the Central Highlands, the Tonkin or perhaps even the Nghe An-Ha Tinh of Guatemala, would seem at first examination to provide considerable support for moral economy. Just as in Vietnam, the region of most intense rebellion is one where the subsistence minimum is threatened by primitive agriculture, acute overpopulation, and unfavorable agricultural ecology. The demands of the state and the pressures of the world market in agricultural commodities are also present in the Highlands although they take a very different form than they did in Vietnam. The failure of the sixties movement in the East also tends to support moral economy theory since the Eastern ladinos were considerably further above the subsistence threshold than were the Indians of the Central Highlands. The peasant union movement is, however, a puzzle for the moral economists since it occurred not in the Highlands, but in the Coffee Piedmont among resident estate laborers at a time when world coffee prices were high and there was therefore no immediate threat to subsistence. An even greater problem, however, is the fact that most of the elements of the subsistence crisis have been present in the Highlands since at least the end of World War II, if not earlier, yet, as the analysis of social change in the Highlands indicates, the receptivity of Highland peasants to guerrilla organization is of extremely recent origin.

There is no doubt that the subsistence margin is and has been in danger in the Central Highlands. Statistics on malnutrition and infant mortality make this tragically clear. By one estimate 81 percent of Guatemalan children under six years of age suffer from malnutrition and 42 percent are born below normal weight due to inadequate maternal nutrition. ${ }^{56}$ The CIDA examined the Civil Register of San Juan Ostuncalco in Quezaltenango and found that children under the age of six constitute 55 percent of all reported deaths in the municipality, and that in Totonicapán 10 percent of all deaths were from malnutrition. ${ }^{57}$ Although export agriculture has sparked a long economic boom, per capita production of food crops did not increase at all between the early fifties and mid-sixties. ${ }^{58}$ Between the 1964 and 1973 censuses the population of the northwest zone of the Central Highlands increased at an annual rate of 2.34 percent, but maize production increased at almost precisely the same rate, 2.39 percent. ${ }^{59}$ The subsistence crisis did not ease but, significantly, neither did it worsen. However, in the seventies the situation improved. Maize production increased at a rate of 5.9 percent between 1973-74 and 1977-78, more than double the historic population growth rate. 
The village studies of Brintnall, Hinshaw and Warren confirm that at least in some areas of the Highlands changes such as the introduction of cash crops, fertilizers, irrigation, and the organization of cooperatives began to dramatically improve Indian agriculture. By 1973 in Aguacatán, for example, despite immense technical difficulties, half of all lands were irrigated. Around Lake Atitlán, Sante Maria Visitación had largely liberated itself from seasonal labor by increased commerce in fruit and vegetables, Panajachel Indians had taken up coffee production and in San Andreas Semetabaj the local wheat growers, whose wealth was based on chemical fertilizers, had expanded their cooperative to include 1,200 members in Sololá, Quiché and Guatemala. ${ }^{60}$ All of these changes, however, benefit only the land-owning members of the communities and there are still plenty of poor landless peasants to supply labor for the coastal plantations. The subsistence crisis seems to have eased in the critical decade of the late sixties and early seventies when, according to moral economy theory, it should have deepened.

Pressures on subsistence reached the crisis stage, however, long before this last decade as careful demographic research by Carmack on the central Quiché Highlands indicates. He estimated that the carrying capacity of maize agriculture under primitive conditions, which were the conditions in most of the Highlands, would support a population of some 50,000 in central Quiché. As the following data indicate, that figure was exceeded as early as the 1920s:61

$\begin{array}{lll}\text { Date } & & \text { Population } \\ 1524 & & 50,000 \text { (estimate) } \\ 1893 & & 55,000 \text { (first census) } \\ 1926 & & 63,000 \\ 1940 & & 78,000 \\ 1950 & & 81,000 \\ 1974 & & 100,000\end{array}$

The subsistence crisis was beginning to be serious by the twenties and was acute by 1940 . This is also evident in the mass recruitment of Highland workers for the lowland coffee estates described by Dessaint in a review of the earlier ethnographic literature on the Highlands. During the thirties and forties entire villages and even sizable towns were depopulated of adult males for much of the year as the men sought employment on the coffee estates. Around Lake Atitlán men from all the villages except the successful capitalists of Panajachel emigrated; Wagley's Chimaltenango was practically empty during October and November of each year, when as few as fifty able-bodied 
men (village population 1500) were left; in San Martín Huehuetenango all of the men seen by Tax seemed to go to the coast for half the year; in Chichicastenango church bells tolled regularly to mourn the death of a migrant on a coastal estate, since as many as 15,000 men from the small city worked there. ${ }^{62}$ Escape from the subsistence crisis was not found in local insurance systems but rather by massive employment in wage labor, much as the peasants of Nghe An worked in the nearby industries of the city of Vinh. ${ }^{63}$

The moral economists, of course, did not say that the subsistence crisis alone created the potential for rebellion. This occurred only if the crisis were combined with human intervention which politicized discontent. Still, if it were the subsistence crisis which triggered the revolt it should have occurred in 1940 , not 1980. Furthermore, the extractions by the state and peasant involvement in the market are also of long standing. In Vietnam the state and the market demanded rice or money; in Guatemala both demanded labor. In Vietnam the French colonial state and its local Vietnamese agents collected taxes while the forces of the market determined the price of rice and the share rents were set by direct negotiations with local landlords. In Guatemala the state and the landlords were virtually indistinguishable and their demands were the same - labor in the coastal estates. There is no doubt that the state threatened the subsistence margin directly by taking time away from subsistence cultivation. The result was the same as in Vietnam, but on a much smaller scale. Colby and van den Berghe report that in Nebaj in 1936 Indians assaulted the local army garrison to protest forced labor and debt servitude in an action reminiscent of the depression era rebellions in Vietnam. It appears that unrest was a chronic problem in Indian communities through much of this century and earlier but before the late seventies it had not, since the early colonial period, led to a general insurrection. ${ }^{64}$ But the state role in labor recruitment was pronounced earlier in the century and, if anything, declined after 1944. Before that time labor was recruited through state enforced debt peonage (1894-1934) or through vagrancy laws (1934-1944) which required 100-150 days labor a year of Indians (but not ladinos). ${ }^{65}$ The state role in labor recruitment diminished after 1944 when the revolution abolished the vagrancy code, but by that time the subsistence crisis was sufficiently advanced to compel migrant labor by economic pressure alone. Thus, the demands of the state, the labor market, and subsistence pressures had all reached a crisis stage by 1940 , but no revolt occurred until almost forty years later. By then, the subsistence crisis had eased, and although the demand for labor persisted, the state's involvement in labor recruitment had declined. When all three variables specified by the theory were present the general insurrecton predicted by the moral economy theory did not occur. Agrarian revolution occurred in the right place but at the wrong time. 


\section{Political Economy}

For political economy theory agrarian revolution occurred in both the wrong time and the wrong place. Theoretically, the guerrillas should have succeeded in the East in the sixties, but of course they did not. Although it is difficult to assess the effectiveness of a clandestine guerrilla organization independent of how powerful an insurrection it organizes, there is considerable evidence that guerrilla organization and tactics in the sixties were not significantly inferior to those of the seventies, and indeed, the two guerrilla movements showed striking similarities. The actions of FAR and MR-13, like those of EGP and ORPA, were about equally divided between military occupations ("armed propaganda") and small scale ambushes on military units. Indeed, the following description of a FAR armed propaganda action could have been taken from an ORPA press release:

... after Panzo's was occupied by the guerrilla squad of commander Turcios, a public meeting was held in the square at which the entire village wa present. The guerrilla squad had confiscated all arms and supplies belonging to the military post; it had bought provisions in local shops, paying prevailing prices. It had then drawn up an agreement which the mayor was obliged to sign in the presence of the villagers. ${ }^{66}$

The structure of the two organizations as well as their largely middle class and student leadership was also similar; in the case of both ORPA and new FAR there are direct structural links between the old and new guerrillas. Indeed, the division of the guerrilla movement into two phases is somewhat arbitrary since the struggle continued at a reduced level during the intervening years. Even the names of the EGP fronts - Turcios Lima, Edgar Ibarra, Otto Rene Castillo - reflect the ideological connections between the two sets of organizations. The development of the ORPA front in Quezaltenango and San Marcos depended on the earlier organizational work of FAR in the late sixties. ${ }^{67}$

The sixties guerrillas also followed Popkin's advice concerning the importance of selective incentives delivered by honest effective political entrepreneurs. Both FAR and MR-13 built their peasant following over a period of years by carefully soliciting and responding to the interests of individual peasants and peasant communities. The principal selective incentive was, of course, land; the Eastern peasantry faced expropriation by expanding cattle ranches that often claimed lands that had been cultivated by peasant communities for years. MR-13 pressured landowners and their administrators and often managed to leave peasants in possession of rent-free land. They instituted a radical tax-cutting program by eliminating the feudal levies of Eastern estate owners. They also established village assemblies for the effec- 
tive disposition of local disputes outside the rancher dominated local courts and even became involved in the settlement of domestic quarrels. These committees also cared for the families of peasants killed by the army. There were never any charges of dishonesty or major scandals involving the guerrillas and they seem to have attained an almost mythical status among the peasantry. ${ }^{68}$ There was also no absence of military training or experience among the military men in the first guerrilla wave: Turcios Lima, for example, had received ranger training at Fort Benning, Georgia. ${ }^{69}$ All the guerrilla leaders became sophisticated ideologues well versed in the tactics and theory of guerrilla movements in Latin America and around the world. They also had Guatemala's greatest poet and, lest cynics suggest that poets do not revolutionaries make, consider the poems of Agustinho Neto and Ernesto Cardenal. Their organizational cadre was in no way inferior to that of later guerrillas, their tactics the same; yet they failed.

Their failure was a result of the limited potential for mobilization of the Eastern peasantry, not the absence of honest, effective political entrepreneurs delivering selective incentives. From the point of view of political economy the East is more promising than the Central Highlands since there are more free resources to distribute and communication is facilitated by a higher level of Spanish literacy. The dirt poor Central Highlands, like Tonkin and Annam, have few incentives, selective or otherwise, to offer anyone. But this analysis ignores the class structure of the Eastern region and this, in the end, appears to have been decisive: “... the majority of their peasant base (were) small ladino property owners who were particularly susceptible to the government's repressive tactics and some of whom even joined the right wing para-military groups. ${ }^{\prime \prime 0}$ Unlike the Central Highlands, here there were many property owners with medium-sized holdings who were threatened by the encroaching ranches but were united to them by property ownership and ladino ethnic background. FAR and MR-13 never managed to reach the Indian population on any significant scale, but the change process in the Highlands was not sufficiently advanced in this period to make such an approach promising. In 1967, while the "Butcher of Zacapa" was doing his evil work in Guatemala, another revolutionary foco led by a talented guerrilla leader with an impressive track record was eliminated in Bolivia. Che Guevera, like FAR and MR-13, had selected a region where property holdings were small; the owners' conservative instincts ended his revolutionary career. ${ }^{71}$ Popkin is right that effective organizational entrepreneurs are indispensable for revolution. But they cannot succeed if the underlying class structure blocks popular support. 
Guatemala: Class Conflict. "No necesitan a los indios"

Neither the subsistence crisis nor the guerrilla organization changed much in the decade preceding the rebellion of the late seventies. The organization of production of Guatemala's agricultural export economy, however, changed fundamentally from the traditional Latin American hacienda system which had dominated coffee production since the 1890s to a new form of agribusiness based on a migratory rural proletariat working in the new export crops of cardamom, sugar, and, above all, cotton. The change produced a conflict between two classes new to Guatemala: cost-conscious capitalists whose principal form of capital was still land, and migratory rural proletarians who still lived in Highland peasant communities. The results of such a collision between capitalists dependent on land, and a rural semi-proletariat was apparent in the Mekong Delta of Vietnam throughout the twentieth century. In Guatemala the conflict is largely a result of changes in agricultural organization in the last twenty, and especially the last ten, years.

Changes in agricultural organization are in large part a result of the introduction of new export crops, although the structure of the traditional coffee hacienda has been undergoing fundamental change as well. As the data in Table 2 make clear, while production in Guatemala's traditional export crops, coffee and bananas, continues to expand, the most dramatic growth has occurred in new crops, the most important of which is cotton. Although between 1960 and 1978 production of coffee and bananas both increased by almost 40 percent production of cotton more than quintupled in the same period and sugar production, starting from a small base, increased to over 150,000 tons by 1978 , nearly tripling in the last decade. Cardamom exports

TABLE 2

Guatemalan Agricultural Exports, 1935-78, in metric tons ${ }^{a}$

\begin{tabular}{lccccc}
\hline Year & Coffee & $\begin{array}{l}\text { Bananas } \\
\text { (stems) }\end{array}$ & Cotton & Sugar & Cardamom \\
\hline 1935 & 40,812 & 5,595 & - & - & - \\
1940 & 41,896 & 5,018 & - & - & - \\
1950 & 54,843 & 6,938 & - & - & 27 \\
1960 & 79,917 & 7,254 & 24,919 & 687 & 447 \\
1970 & 95,080 & 6,908 & 100,467 & 57,344 & N.A. \\
1978 & 131,557 & $10,050^{*}$ & 131,557 & 152,954 & N.A. \\
\hline
\end{tabular}

* Estimated from weight.

a. Source: Direccion General de Estadistica, no date, 1976, 1980; Adams 1978:357. 
experienced a dramatic increase a decade earlier and, although the quantity by weight is small, this is an extremely valuable spice much prized in the Middle East. All of these new export crops as well as the traditional banana crop are produced in the lower agricultural zones of the South Coast; and this region has also experienced a dramatic expansion of commercial cattle production for export. The long economic boom that Guatemala has experienced in the last two decades is directly attributable to the dramatic expansion of the South Coast agricultural zone.

These new export crops were produced in new forms of agricultural organization rather than in the traditional hacienda which was ill-suited to the high land values and intensive, rationalized production of the South Coast. The hacienda, however, served as the principal vehicle for Guatemalan export production from 1890 until recently and, although modified in form, continues to be important in coffee production. The traditional landowner, concerned about securing a captive labor supply, lured peasant laborers to his estate by giving them small plots of land on which to cultivate subsistence crops in exchange for labor on his estate when it was needed. ${ }^{72}$ The workers, called colonos or mozos, were essentially sub-subsistence farmers (minifundistas) who happened to live on an estate and shared many of the social and political characteristics of mini-subsistence farmers of the Highlands or, for that matter, of Tonkin and Annam. Hoyt, describing the situation in 1946-47, notes that the hacienda left Indian culture unchanged and that workers seem unconcerned with changing conditions. ${ }^{73}$ About the latter she was almost certainly wrong since, as we have seen, these workers were active in the peasant union movement less than a decade later. Still, the atmosphere of the hacienda was paternalistic and tightly controlled by the estate owner who held judicial as well as economic power over his workers.

Elsewhere in Latin America, notably in Mexico and Peru, hacienda tenants have resisted peasant revolutionary movements begun by independent communities, and the combination of stable access to a subsistence plot and tight landlord control does not seem to be conducive to mobilization. ${ }^{74}$ Both Riklin and Hoyt call the hacienda "feudal" by which they mean manorial, but there is little doubt that as Riklin observes of two farms in the San Pablo region of Quiché “... they are a twentieth century incarnation of medieval European feudal estates." 75 The landlord's control of his tenant was complete. A landowner in San Pablo forbade his tenants to congregate in groups greater than five and threatened to shoot any priest who set foot on his property; ${ }^{76}$ in $1946-47$ it was still common for landowners to keep a jail on their property where they placed offenders against hacienda rules; ${ }^{77}$ and landowners were so suspicious of outsiders in the early sixties that they 
refused to allow agricultural extension agents on their property. ${ }^{78}$ On one of Hoyt's estates there had been a radio at one time but the owner took it away because it gave so much time (he claimed) to labor propaganda. ${ }^{79}$ The owner provided inadequate housing and sometimes took care of older residents after their working lives were over, but he could easily withdraw these privileges at will. Under these circumstances it is surprising not that there was so little labor organization, but rather, so much. During times of national crisis, like the Arbenz period when landlord control was dramatically weakened, such peasants could and did organize on a massive scale. But such times are the exception.

Many of the estate workers were, of course, nonresident migrants from the Central Highlands, but they lived in temporary barracks-like quarters and were clearly subordinate to and largely controlled by both the residential community of permanent tenants and the hacienda administration. The traditional proportion of resident labor was approximately 45 percent; Hoyt reports 12,000 permanent and 16,000 temporary workers on the fifty estates she surveyed; the CIDA found a total of 651 resident and 900 temporary workers in the six Coffee Piedmont estates it surveyed and Schmid found a total of 80,385 resident and 99,000 migrant workers in coffee production in $1950 .{ }^{80}$ With such a large proportion of year-round permanent residents it would be difficult for much independent political organization to develop among the migrants. Furthermore, the migrants were tightly controlled by ladino labor contractors, the enganchadores (v.t. enganchar, to hook), who completely monopolized access to estate labor.$^{81}$ To work as a migrant meant first subordinating oneself to a ladino contractor, then to the estate residential community, and finally to the landlord's law. Contractor, community, and landlord all reinforced traditional patterns of Indian subordination and ladino domination. Perhaps this is why San Miguel Acatán, where in 1981 peasants died shouting "long live the revolution," was known in the thirties as "A good village for plantation labor because Indians generally had no serious objections to this type of work." 82 Those with serious objections, of course, could find no ladinos to supply them with work.

Stockpiling resident estate labor may have had some utility before the subsistence crisis forced Highlanders into the migratory labor stream, but after 1940 the organization of the hacienda with its inefficent use of land and labor and backward technology could not long survive the rationalizing forces of the international commodity market. As Quan observes, "with the increased possibilities of mechanization, a more than adequate labor supply, and the increasing value of land, this system is no longer the most advantageous for the landowner, and the colono is fast disappearing." ${ }^{.3}$ The resident 
Indian estate laborer in export agriculture has become expendable. The current attitude toward Indian resident labor is well-expressed by the chilling phrase heard increasingly in Central America: "No necesitan a los indios" (We don't need the Indians anymore). ${ }^{84}$ What is needed is labor reduced to commodity status, not Indian residential communities that eat up land and resources. The colono system never made any headway on the South Coast which was, from the beginning, organized along rational capitalist lines. In the early sixties the CIDA found that such attitudes were the most striking difference between estate owners in the Coffee Piedmont and the South Coast. South Coast planters were enthusiasts for new ideas and the latest technology; they invested heavily in estate improvements and were not afraid to take risks. According to the CIDA the owners of the most modern coastal estates also wanted to get rid of their permanent laborers to avoid problems of under-employment, evade labor legislation, and rationalize manual work. ${ }^{85}$ To a large extent they have succeeded. Thus it is not surprising to find that the ratio of temporary to permanent laborers is higher on the Coast than in the Coffee Piedmont. Adams estimates that there were 4,700 permanent employees and laborers on cotton farms in 1965-66, while there were between 118,000 and 150,000 migrant laborers. ${ }^{86}$ Although the South Coast planters have dispensed with resident Indian communities, they have not dispensed with the need for Indian labor. Their economic success ultimately rests on acute deprivation in the Central Highlands.

Even in the Coffee Piedmont the hacienda system is beginning to break down. While in 1950 the resident laborers constituted 45 percent of all laborers, by 1960 their proportion was down to about a third. With this change to migratory rather than resident labor in coffee, and the continued expansion of the South Coast migratory labor system, came a fundamental change in the pattern of class relations. The only connection between the South Coast agribusinessman and his worker is money during the harvest season. The rest of the year the worker fends for himself beyond the reach of estate administrative coercion. Since there are no longer extensive residential communities of colonos, the inhibiting effect of this conservative strata is removed. Finally, labor recruiting in cotton seems to have slipped out of ladino hands and is now controlled by a new class of Indian entrepreneurs. ${ }^{87}$ Since the Indian migrants now obtain half or more of their subsistence from the South Coast economy their dependence on the good will of local landowners in the Highlands is also greatly reduced. To many Indians it must appear that it is the ladinos who are expendable. The fundamental changes which have come to the Indian villages of the Highlands, then, are a result of the fact that many of these villages are not peasant at all but rather temporary homes for agricultural wage laborers. Typical of the effect of such changes is 
Brintnall's description of how peasant leagues came to Aguacatán. They came in the person of a coastal labor organizer brought to the village by a native returning from seasonal labor. Focusing on labor issues, not on traditional peasant land disputes, the organizer had great success, but only among the poor members of the village, who were still largely dependent on coastal labor, and had not benefitted from the improvements in agriculture in the Highlands. By 1975 there were two noncompetitive leagues with over two hundred members. Poor ladinos as well as Indians were admitted, an unheard of breach of local racial etiquette. ${ }^{88}$ Here was the peasant organization that Turcios's men had sought in vain in the sixties. Aguacatán, as was indicated earlier, is, of course, in the center of current EGP operations including a recent claymorazo.

The collapse of the hacienda system and the increasing independence of Indians in agro-export wage labor is also evident in Riklin's account of the origins of a protest march on the Guatemalan congress by twenty-seven Indians from the remote Quiché villages of San Pablo and Chimel. ${ }^{89}$ The problems started when the owner of El Soch, a nearby coffee estate, ordered the peasants, under penalty of death, to make a one and a half hour detour around his estate to go to market. In the past the Indians would have grudgingly obeyed. But, of course, times have changed. The EGP retaliated by killing the owner of El Soch on August 12, 1980 and on August 19 army reprisals, in the form of kidnappings, began. The villages of the Highlands had been long accustomed to losing men to kidnappers both for the army and for forced labor. But this time instead of acquiescing they went to the capital, an act of unheard-of audacity.

The farmers of Chimel and San Pablo are dependent on Coastal wage labor for half or more of their subsistence. They spent that money at the market, which could now be reached only by a forced detour around El Soch. El Soch itself and the adjoining farm of El Rosario are both in economic difficulties since they are traditional haciendas worked by resident colonos and their low productivity and poor management have made them increasingly uncompetitive in a coffee economy dominated by agribusiness. It was not the residents of the traditional commercial haciendas who went to Guatemala City but rather the migratory wage laborers who still lived in the independent villages of San Pablo and Chimel. From hacienda to migratory labor estate and from Indian to proletarian: the changes in San Pablo are a microcosm of the shifts in the Guatemalan agricultural economy as a whole. It is these changes, not the subsistence crisis or the EGP's superior organization, which have created the conditions for revolution in the Central Highlands of Guatemala. 
There is one more piece of evidence supporting the class-conflict interpretation, although it is not beyond dispute: the theories of the guerrillas themselves. As was the case in Vietnam, successful political entrepreneurs seem to view their struggle in class-conflict terms. Here is the EGP's position from its magazine Compañero.

... poor peasants ... minifundistas (owners of sub-subsistence plots) have no other choice than to migrate periodically to the coast, if they are to survive. This reality constitutes one aspect of the inextricable relationship between the latifundio and the minifundio; the other aspect is the landowners' reliance on this migrant labor force... Within this process of capitalist transformation, the Indian peasants have become wage workers part of the year or semi-proletarians..$^{90}$ (Italics mine.)

According to the EGP the Indians' only choice is to join the Popular Revolutionary War and it is clear that it is these "semi-proletarians" that it expects will join.

The transformation from hacienda to agribusiness has had one other major effect on the Highland peasantry. Increasing land values and prospects for agro-export development have precipitated large-scale land grabs throughout the Highlands, particularly in the so-called Northern Transversal Strip which includes the northern third of Huehuetenango, El Quiché, and Alta Verapaz. ${ }^{91}$ General Romeo Lucas Garcia himself, Guatemala's most recently deposed presidential general, is rumored to personally own a substantial tract in the area, variously estimated from 18,000 , to 130,000 acres. ${ }^{92}$ Other large tracts are owned by many other officers as well as by a "who's who of Guatemalan society." 93 The area is also becoming important as a possible southern extension of the great Mexican petroleum fields ${ }^{94}$ All of this wealth sits under land occupied by Indian communities and traditional haciendas. No necesitan a los indios. The generals' current slaughter of entire Indian villages at Chajul, Cotzal, Nebaj, San Miguel Acatán, San Martín Jilotepeque, and Panzos in this region combines a grim economic as well as political logic. Eliminating the population will eliminate the guerrillas and also free the land for development. The parasitic relationship between the hacien$\mathrm{da}$ and the Indian village is being destroyed by military agribusinessmen whose viciousness apparently knows no limits. If they survive the generals' onslaught, the peasants' last connection to the land will be severed and they will be completely dependent on agro-export wage labor.

In their long involvement in Vietnam, Americans never listened to the revolutionaries' own account of the origins of their conflict. Had they, they would have heard the same message as in the passage from the EGP quoted above: class conflict generated by the collision between an agricultural 
proletariat and capitalist landowners in a peripheral export economy has the power to generate revolutionary conflict of explosive power. In Vietnam the conflict was between landowners and share tenants, in Guatemala it is between military agribusinessmen and migratory proletarians, but the results have been remarkably similar. Neither moral economy nor political economy has the power to explain the origins of the conflict in both nations or to reflect the views of the revolutionaries themselves. Perhaps it would not surprise Marx to learn that careful analysis of the organization of production would provide the key to an understanding of revolutionary change, but it seems to be something of a surprise to recent theorists of peasant revolution. It is a lesson that they could well take to heart.

\section{Notes}

1. Philip Caputo, A Rumor of War (New York: Holt, Rinehart and Winston, 1977), 44; Yves Henry, Economie agricole de l'Indochine (Hanoi: Governement General de l'Indochine, 1932); Pierre Gourou, The Peasants of the Tonkin Delta (New Haven: Human Relations Area Files, 1955). Originally published as Les Paysans du Delta Tonkinois, (Paris: Editions d'Art et d'Histoire, 1936); James C. Scott, "Peasant Revolution: A Dismal Science," Comparative Politics 9 (1977), 21.

2. Samuel L. Popkin, The Rational Peasant (Berkeley: University of California Press, 1979); James C. Scott, The Moral Economy of the Peasant (New Haven: Yale University Press, 1976); Eric Wolf, Peasant Wars of the Twentieth Century (New York: Harper \& Row, 1968); Joel Migdal, Peasants, Politics and Revolution (Princeton: Princeton University Press, 1974); John T. McAlister Jr. and Paul Mus, The Vietnamese and Their Revolution (New York: Harper \& Row, 1970); Frances Fitzgerald, Fire in the Lake: The Vietnamese and the Americans in Vietnam (New York: Random House, 1972).

3. Norman Frohlich, Joe A. Oppenheimer, and Oran R. Young, Political Leadership and Collective Goods (Princeton: Princeton University Press, 1971); Mancur Olson, The Logic of Collective Action (Cambridge: Harvard University Press, 1965); Brian Barry, Sociologists, Economists and Democracy (London: Macmillan, 1970); Edward Banfield, The Moral Basis of a Backward Society (New York: Free Press, 1968).

4. Jeffery M. Paige, Agrarian Revolution (New York: The Free Press, 1975); Vo Nguyen Giap and Truong Chinh, The Peasant Question (1937-38) trans. Christine Peltzer White. Southeast Asia Program Data Paper \#94 (Ithaca: Cornell University Press, 1974).

5. Charles Tilly, From Mobilization to Revolution (Reading, Mass.: Addison-Wesley, 1978), 24. Tilly's typology includes a fourth tradition, the Weberian, which has no clear representative among scholarly theories about Vietnam.

6. Popkin, Rational Peasant, xiii; Tilly, Mobilization, 27-28.

7. Gourou, Tonkin Delta, 311 quoted in Popkin, Rational Peasant, frontispiece.

8. R. H. Tawney, Land and Labor in China (Boston: Beacon Press, 1966), 77 quoted in Scott, Moral Economy, 1.

9. Wolf, Peasant Wars, 295.

10. Tilly, Mobilization, 10.

11. Popkin, Rational Peasant, 5-15.

12. Eric Wolf, Peasants (Englewood Cliffs, N.J.: Prentice Hall), 12.

13. Popkin, Rational Peasant, 248, 249-50.

14. Edward J. Mitchell, "Land Tenure and Rebellion: A Statistical Analysis of Factors Affecting Government Control in South Vietnam," Rand Memorandum 5181-ARPA, Santa Monica, California. Also published as "Inequality and Insurgency: A Statistical Study of Vietnam," World Politics 20 (1968), 421-38.

15. Popkin, Rational Peasant; Paige, Agrarian Revolution; Eric Wolf, "Review Essay: Why Cultivators Rebel," American Journal of Sociology 83 (1977), 742-50.

16. Bernard Fall, "South Vietnam's Internal Problems," Pacific Affairs 31 (1958), 241-60.

17. Paige, Agrarian Revolution, 71.

18. Jeronimo Camposeco, "A Testimony on Guatemala," paper presented at the Conference on Land Tenure in Central America, Johns Hopkins University (Washington, D.C.: Washington Office on Latin America, 1981). 
19. Neal J. Pearson, "Guatemala: The Peasant Union Movement," in Latin American Peasant Movements, ed. Henry Landsberger (Ithaca: Cornell University Press, 1969), 323-73; Brian Murphy, "The Stunted Growth of Campesino Organizations," in Crucifixion by Power, general author Richard Newbold Adams (Austin: University of Texas Press, 1970), 438-78.

20. North American Congress on Latin America (NACLA), Guatemala (Berkeley: NACLA, 1974), 185; Thomas Melville and Majorie M. Melville, Guatemala: The Politics of Land Ownership (New York: The Free Press, 1971), 1; Richard Gott, Guerrilla Movements in Latin America (Garden City, N.J.: Anchor, 1972), 99-100.

21. Adolfo Gilly, "The Guerrilla Movement in Guatemala," Monthly Review 17 (May 1965), 30.

22. Noticias de Guatemala, 4 May 1981, 19

23. Quoted in NACLA, Guatemala, 1983.

24. Nathan L. Whetten, Guatemala: The Land and the People (New Haven: Yale University Press, 1961), 8-16; Comite Interamericano de Desarrollo Agricola (CIDA), Tenencia de la Tierra y Desarrollo Socio-Economico del Sector Agricola: Guatemala (Washington, D.C.: Panamerican Union, 1965), 2-3; Robert C. West and John P. Augelli, Middle America: Its Lands and Peoples, 2nd ed. (Englewood Cliffs, N.J.: Prentice-Hall, 1976), 408.

25. West and Augelli, Middle America, 408.

26. Richard Newbold Adams, Crucifixion by Power (Austin: University of Texas Press, 1970), 353-379.

27. Guatemala, Direccion General de Estadistica, Anuario Estadistico 1974 (Guatemala City, 1976), Cuadro 4.

28. Allain X. Dessaint, "Effects of the Hacienda and Plantation Systems on Guatemala's Indians," America Indigena 22 (1962), 332.

29. Guatemala, Anuario Estadistico 1974, 70, Cuadro 3.

30. Neal J. Pearson, "Guatemala: The Peasant Union Movement," in Latin American Peasant Movements, ed. Henry Landsberger (Ithaca: Cornell University Press, 1969), 323-73.

31. Ibid., 350 .

32. Gott, Guerrilla Movements, 32.

33. Gilly, "Guerrilla Movement," (May 1965), 14.

34. Ibid., 17.

35. Gilly, "Guerrilla Movement," (May 1965), 18-19; Gott, Guerrilla Movements, 52; NACLA, Guatemala, 184.

36. Gilly, "Guerrilla Movement," (June 1965), 32.

37. NACLA, Guatemala, $185,187$.

38. Gilly, "Guerrilla Movement," (May 1965), 16-17.

39. Otto Rene Castillo, Let's Go! Selections from Vamanos Patria a Caminar, trans. Margaret Randall (London: Cape Goliard Press, 1971).

40. Gilly, "Guerrilla Movement," (June 1965), 25.

41. NACLA, Guatemala, 183, 191.

42. Le Monde, 7 February 1966, quoted in Gott, Guerrilla Movements, 56.

43. Green Revolution, "Guatemala! The Terrible Repression and its Roots in the U.S. National Security State," (Winter 1980).

44. Charles Wagley, The Social and Religious Life of a Guatemalan Village, American Anthropological Association, Memoire 71 (1949); Sol Tax, Penny Capitalism: A Guatemalan Indian Economy, Smithsonian Institution, Institute of Social Anthropology, no. 16 (Washington, D.C., 1953); Ruth Bunzel, Chichicastenango, American Ethnological Society, Publication 22 (1952); Melvin M. Tumin, Caste in a Peasant Society (Princeton: Princeton University Press, 1952).

45. Charles Wagley, "Foreward," in Revolt Against the Dead by Douglass Brintnall, (New York: Gordon and Breach, 1979).

46. Tax, Penny Capitalism.

47. The Guardian, 16 September 1981, 13.

48. Noticias de Guatemala, 4 May 1981, 4.

49. Benjamin N. Colby and Pierre L. van den Berghe, Ixil Country (Berkeley: University of California Press, 1969).

50. New York Times, 9 May 1981, 4.

51. Colby and van den Berghe, Ixil Country, 178.

52. Douglas Brintnall, Revolt Against the Dead (New York: Gordon and Breach, 1979), 33.

53. Noticias de Guatemala, 23 March 1981.

54. Robert Hinshaw, Panajachel: A Guatemalan Town in Thirty Year Perspective (Pittsburgh: University of Pittsburgh Press, 1975).

55. Kay B. Warren, The Symbolism of Subordination (Austin: University of Texas Press, 1978).

56. Julio Quan, "Guatemalan Agriculture in 1981," paper presented at the Conference on Land Tenure in Central America, Johns Hopkins University (Washington, D.C. Washington Office on Latin America, 1981), 17.

57. CIDA, Tenencia de la Tierra, 109-110.

58. Adams, Crucifixion, 152. 
59. Guatemala, Direccion General de Estadistica, Guatemala en Cifras 1964 (Guatemala City, n.d.); Idem., Anuario Estadistico 1978 (Guatemala City, 1980).

60. For Aguacatán see Brintnall, Revolt, 113; Santa Maria Visitacion and Panjachel, Hinshaw, Panajachel, 164, 172; Semetabaj, Warren, Symbolism, 157.

61. Robert M. Carmack, The Quiche Mayas of Utatlan (Norman: University of Oklahoma Press, 1981), 104-105.

62. Dessaint, "Hacienda and Plantation," 338-339.

63. Scott, Moral Economy, 136-137.

64. Colby and van den Berghe, Ixil Country, 155; Unrest in Indian communities, see Jean Loup Herbert, "Expresiones Ideologicas de la Lucha de Clases y de la Discriminacion Racial Institucional a su Mixtificacion: El Indigenismo," in Guatemala: Una Interpretacion Historico-Social, eds. Carlos Guzman Blocker and Jean-Loup Herbert (Mexico: Siglo XXI Editores, 1970).

65. Whetten, Guatemala, 120-121; Dessaint, "Hacienda and Plantation," 331.

66. Gilly, "Guerrilla Movement," Monthly Review, (June 1965), 18-19. See also Ibid., (May 1965), 20-22. NACLA, Guatemala, 182-184.

67. Julio Quan personal communication.

68. Gilly, "Guerrilla Movement," (May 1965), 11; Ibid,, (June 1965), 15-16; Eduardo Galeano, Guatemala Occupied Country (New York: Modern Reader, 1967), 31-32.

69. Gott, Guerrilla Movements, 49.

70. NACLA, Guatemala, 186.

71. Gott, Guerrilla Movements, 481.

72. Elizabeth Hoyt, "The Indian Laborer on Guatemalan Coffee Fincas," Inter-American Economic Affairs 9 (1955), 33-46; Dessaint, "Hacienda and Plantation;" CIDA, Tenencia de la Tierra; Scott Riklin, "Guatemala: The Revolution Approaches," mimeographed (Rye, New York, 1980).

73. Hoyt, "Indian Laborer," 41-46.

74. Mexico, John Womack, Zapata and the Mexican Revolution(New York: Random House, 1968), 43-50; Peru, Paige, Agrarian Revolution, 204.

75. Riklin, "Revolution," 10.

76. Ibid.

77. Hoyt, "Indian Laborer," 34.

78. CIDA, Tenencia de la Tierra, 81.

79. Hoyt, "Indian Laborer," 37.

80. CIDA, Tenencia de la Tierra, 85; Lester Schmid, "The Role of Migratory Labor in the Economic Development of Guatemala" (Ph.D. diss., University of Wisconsin, 1967), quoted in Adams, Crucifixion, 392.

81. Brintnall, Revolt, 108.

82. Dessaint, "Hacienda and Plantation," 341.

83. Quan, "Guatemalan Agriculture," 14.

84. I am indebted to Gilma Tinoco for this observation.

85. CIDA, Tenencia de la Tierra, 81-82.

86. Adams, Crucifixion, 369.

87. Brintnall, Revolt, 154.

88. Ibid., 163 .

89. Riklin, "Revolution," 10.

90. Companero, n.d. (probably 1981), 7.

91. Riklin, "Revolution;" International Work Group for Indigenous Affairs (IWGIA), Guatemala 1978: The Massacre at Panzos, IWGIA Doccument 33 (Copenhagen, 1978).

92. Riklin estimates 18,000 ("Revolution," 8.); IWGIA quoting Newsweek, 78,000 (Panzos, 11); and Camposeco, 100,000 (Camposeco, "Testimony," 8).

93. Riklin, "Revolution," 8.

94. New York Times, 8 May 1981, 29.

\section{Acknowledgments}

This is a revised version of a paper presented at the Conference on Global Crises and Social Movements (Santa Cruz, California, 24 October 1982), and circulated as Working Paper 275, Center for Research on Social Organization, University of Michigan. The data on which the analysis is based extend to August 1981 and so do not reflect more recent developments, especially the rapidly changing situation after the counter-revolutionary 
offensive launched by Efrain Rios Montt in July 1982. I am grateful to Ellisa Miller for allowing me access to her collection of contemporary Guatemalan opposition publications and to members of the Guatemalan church in exile, who must remain anonymous, for much helpful information. 